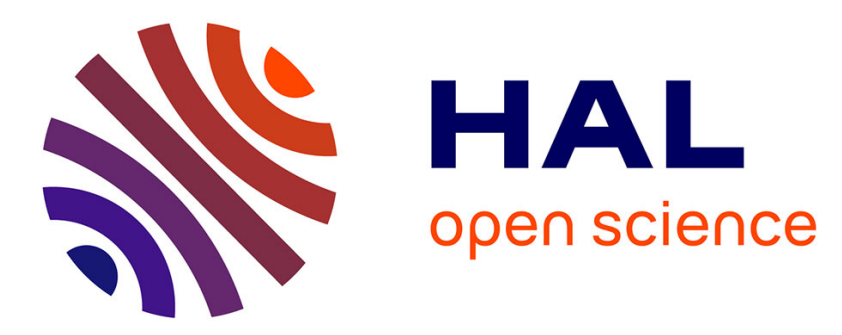

\title{
Endocrine changes associated with spawning behavior and social stimuli in a wild population of rainbow trout (Salmo Gairdneri). I. Males.
}

\author{
N.R. Liley, Bernard Breton, Alexis Fostier, E.S.P. Tan
}

\section{To cite this version:}

N.R. Liley, Bernard Breton, Alexis Fostier, E.S.P. Tan. Endocrine changes associated with spawning behavior and social stimuli in a wild population of rainbow trout (Salmo Gairdneri). I. Males.. General and Comparative Endocrinology, 1986, 62, pp.145-156. 10.1016/0016-6480(86)90103-6 . hal02728617

\section{HAL Id: hal-02728617 \\ https://hal.inrae.fr/hal-02728617}

Submitted on 2 Jun 2020

HAL is a multi-disciplinary open access archive for the deposit and dissemination of scientific research documents, whether they are published or not. The documents may come from teaching and research institutions in France or abroad, or from public or private research centers.
L'archive ouverte pluridisciplinaire HAL, est destinée au dépôt et à la diffusion de documents scientifiques de niveau recherche, publiés ou non, émanant des établissements d'enseignement et de recherche français ou étrangers, des laboratoires publics ou privés.

\section{다(1)(2)}

Distributed under a Creative Commons Attribution - ShareAlikel 4.0 International 


\title{
Endocrine Changes Associated with Spawning Behavior and Social Stimuli in a Wild Population of Rainbow Trout (Salmo gairdneri)
}

\author{
I. Males
}

\author{
N. R. Liley, ${ }^{*}$ B. Breton, $\dagger$ A. Fostier, $\dagger$ and E. S. P. Tan $\dagger$ \\ *Department of Zoology, University of British Columbia, Vancouver, B.C., Canada; \\ $\div$ Laboratoire de Physiologie des Poissons, INRA, Bat. no. A, Campus de Beaulieu, 35042 Rennes, France; \\ and $¥$ School of Biological Sciences, Universiti Sains Malaysia, Penang, Mataysia
}

Accepted November 7, 1985

\begin{abstract}
Kainbow trout (Salmo gairdneri) were collected from a natural spawning population at Pennask Lake, B.C. Blood samples were taken from male trout at different stages of spawning and assayed by radioimmunoassay for gonadotropin $(\mathrm{GtH})$, testosterone ( $\mathrm{T}), 11$ -

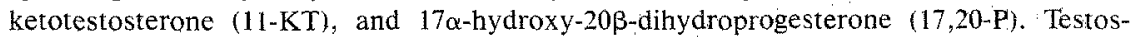
terone and 11-KT were detected in the plasma of males in spawning condition: 11-KT was at a higher concentration than $\mathrm{T}$ and declined to undetectable levels in postspawning fish. There were striking increases in plasma GtH and 17,20-P in males actively courting nest building females. The increase in 17,20-P was evidently not dependent upon an elevation of the pituitary hormone: 17,20 -P remained low in males placed with sexually inactive, unovulated females even though GtII levels rose above levels measured in males isolated from females. The significance of the social control of hormone levels is not clear. There is some evidence that $17,20-\mathrm{P}$ and/or GtH may cause an increase in quantity of the milt, and thus the endocrine response to a sexually active female may serve to synchronize maximum male fertility with oviposition readiness in the female. (c) 1986 Academic Press. Inc.
\end{abstract}

There has been considerable progress in recent years in describing the annual or seasonal endocrine changes associated with reproduction in teleost fish (recent reviews by Fostier et al., 1983; Peter, 1983). However, much less is known of the acute "short-term" endocrine changes occurring during spawning (Stacey et al., 1984).

The functional significance of many of the observed endocrine events is still far from clear, particularly as they relate to the behavioral processes involved in spawning (Liley and Stacey, 1983). A major reason for the lack of understanding of the behavioral role of gonadal and other hormones is that most studies have concerned captive fish not allowed to participate in a normal spawning process. This is particularly true of investigations involving domesticated strains of rainbow trout, many generations removed from their wild progenitors. It is possible that the levels and changes in hormones observed in laboratory situations may not be an accurate guide to naturally occurring events (e.g., Licht et al., 1983, found that in the bullfrog, Rana catesbeiana, plasma gonadotropins and steroids are highly sensitive to the effects of captivity).

A major factor potentially responsible for differences between restrained laboratory and naturally spawning fish is the two-way relationship between the endocrine system and the biological and physical environment: not only does the endocrine system regulate the behavioral responses necessary for successful reproduction, but it is also responsive to social and other exogenous stimuli (Harding, 1981). Studies with birds in particular (review by Silver and Cooper, 1983) have demonstrated that the smooth progression through the repro- 
ductive cycle depends upon the continual interplay between the endocrine system and the environment.

The role of major physical features of the environment-photoperiod, temperature, lunar and tidal rhythms - have been examined in many species of teleost (Lam, 1983; Peter, 1983). Less is known of the role of more immediate physical and social stimuli. A number of studies, reviewed by Liley (1980) and Lam (1983), indicate the role of chemical and behavioral signals in accelerating or synchronizing breeding in fish. Presumably, effects of this nature are mediated by the endocrine system. Direct evidence of behaviorally induced endocrine changes is provided by Kyle et al. (1982, 1985) who found a rapid increase in plasma gonadotropin in male goldfish exposed to a spawning pair.

For a better understanding of the relationship between endocrine and reproductive events, it is necessary to assay hormone levels in fish undergoing a natural spawning. Schmidt and Idler (1962), Crim et al. (1975), Stuart-Kregor et al. (1981), Hunt et al. (1982), and Ueda et al. (1983b, 1984) have provided an overview of the endocrine events associated with the migration from the sea to the spawning areas in Pacific and Atlantic salmon. Stacey et al. (1984) and Scott et al. (1984) have provided a detailed account of the endocrine events in white suckers Catostomus commersoni through the spawning cyclc. Nonc of these investigations involved detailed behavioral observations of the individuals sampled for hormone assay.

In the present study blood hormone levels in wild-caught male rainbow trout were assayed at different stages of the natural spawning cycle. The objectives of this approach were: (a) to compare the plasma hormone profiles of wild fish with those obtained in hatchery stocks, (b) to obtain information on acute, short-term hormonal changes associated with particular events during spawning, pcrhaps providing information on possible causal relationships be- tween endocrine factors and behavior, and (c) to evaluate the influence of certain social and physical stimuli on the endocrine condition of the fish.

\section{MATERIALS AND METHODS}

(a) Fish stocks. Fish were taken from a population spawning in the inlet to Pennask Lake (approx $940 \mathrm{ha}$ ) $50 \mathrm{~km}$ east of Merritt. B.C. $\left(50^{\circ} 0^{\prime} \mathrm{N} ; 120^{\circ} 8^{\prime} \mathrm{W}\right.$; altitude $1402 \mathrm{~m}$ ). Most females spawn at 3 years; a few 4-year-old spawners occur. The majority of spawning males are 3 years old, but precocious ( 2 year) and older (4 year) males also spawn. The majority, if not all, die after one spawning season.

Shortly after the ice disappears from the lake in early May fish move into outlet and inlet streams. Fish in the outlet stream spawn at the end of May and early June. In the inlet, spawning commences in early June, peaks in the 3rd or 4th week of June, and persists into early July.

The British Columbia Ministry of Environment Fisheries Branch operates traps on the inlet and outlet streams. Once the required number of eggs is collected the traps are opened and the fish allowed to move on to the natural spawning areas. Fish used in this study were collected at the trap on the inlet stream.

(b) Holding and experimental facilities. In 1982, blood samples were taken immediately after fish were collected from the trap, or at various times after fish were placed in wooden or fiberglass troughs approximately $200 \times 45 \times 45 \mathrm{~cm}$ high, enclosed at both ends and above with wire netting. The troughs were placed in the stream and held down by gravel and rocks at a depth of $20-25 \mathrm{~cm}$. Over the main sampling period, June 14-30, water temperaturc ranged from 10 to $14^{\circ}$. After heavy rain and snow water temperature dropped to $6^{\circ}$ on July 4.

In 1983, fish were transported to the laboratory in Vancouver where they were placed, within $10 \mathrm{hr}$ of collection, in flowing dechlorinated tap water in a series of holding tanks ( $800-1600$ liter). Observation facilities consisted of three oval fiberglass spawning channels, each with an independent water supply. The straight portions of each channel $(190 \times 45 \times 45 \mathrm{~cm}$ and fitted with clear-glass panels on both sides) were isolated from the semicircular ends by wire mesh partitions; each straight section could be subdivided into two $95-\mathrm{cm}$ long sections.

Gravel and sand $(<2 \mathrm{~cm}$ maximum diameter) was placed in each straight section to a depth of $5-8 \mathrm{~cm}$. Water depth was $30 \mathrm{~cm}$ and temperature was maintained at $10 \pm 0.5^{\circ}$. A constant flow $(0.12 \mathrm{~m} / \mathrm{sec})$ of water was maintained by two submersible pumps resting on the bottom of the channel at each end.

(c) Collection of blood samples. Fish were anesthe- 
ized with MS222 and weighed and measured. Blood was collected by caudal puncture using a heparinized 3 -ml syringe fitted with 22-gauge needle. Fish sampled once, mainly the 19.82 series, provided $2-3 \mathrm{ml}$ blood: $1-1.5 \mathrm{ml}$ was taken from fish sampled serially (1983). Blood was held over ice in a cool box until centrifugation $(5 \mathrm{~min}$ at $2000 \mathrm{~g}$ ) usually less than $5 \mathrm{~min}$ after collection. Plasma was stored on dry ice until transfer to a deep freeze at $-80^{\circ}$. Fish to be observed or resampled were given a numbered tag of plastic tape attached by a loup of monofilament line through the muscle just below the anterior rays of the dorsal fin.

Blood samples were collected between 1000 and $1600 \mathrm{hr}$ in 1982 . In 1983 most samplcs were taken between 1000 and $1200 \mathrm{hr}$; a small number were collected up to $1600 \mathrm{hr}$. There is no reason to suspect that blood samples from different experimental groups were consistently collected at different stages of the daily fluctuations in plasma hormones described by a number of investigators (review by Zohar and Billard. 1984).

(d) Hormone assays. Hormone levels have been measured by means of specific radioimmunoassays.

(i) 11-Ketotestosterone (11-KT) assay was performed according to Fostier et al. (1982). The main cross-reactivities, estimated by the ratio of mass of reference to mass of steroid required to decrease the bound label to half its initial value, were $1.1 \%$ for testosterone and $1 \%$ for $11 \beta$-hydroxytestosterone: In the present assay the coefficient of variation was $9 \%$ (30.9 $\mathrm{ng} / \mathrm{ml}, n=5$ ).

(ii) Testosterone $(\mathrm{T})$ assay followed the same procedure as for 11-ketotestosterone, but using an anti-testosterone-3-carboxy methyloxime-bovine serum albumin. Cross reactivities were $41 \%$ with $5 \alpha$-dihydrotestosterone, $31 \%$ with $11-$ ketotestosterone, $14 \%$ with androstenedione, $6 \%$ with $5 \alpha$ androstan-3 $3,17 \beta$ diol. $2 \%$ with 5 androstan- $3 \beta ; 17 \beta$ diol, $0.2 \%$ with adrenosterone and androsterone, less than $0.1 \%$ with dehydroepiandrosterone.

(iii) $17 \alpha$-Hydroxy-20ß-dihydroprogesterone $(17,20$ P) was measured according to the procedure described by Fostier $e$ t al: (1981). The main cross-reactivity was detected with $20 \beta$-dihydroprogesterone $(2 \%)$. In the present assay coefficient of variation was estimated to be $11 \%(8.8 \mathrm{ng} / \mathrm{ml}, n=15)$.

(iv) Gonadotropin was assayed by the procedure described by Breton et al. (1978).

(e) Spawning behavior. Tautz and Groot (1975) provide a detailed qualitative and quantitive description of spawning beliavior in rainbow trout. The following general account provides a basis for the subdivision of the spawning cycle.

Shortly after ovulation a female initiates spawning activity by selecting a nest site and beginning to dig a nest. Digging, which consists of a series of strong body flexures while turned on one side, creates a nest depression $10-15 \mathrm{~cm}$ deep by displacing gravel down stream of the nest site. Bouts of digging are interspersed between periods of holding of probing. A holding female hovers over the nest for a few seconds to several minutes. In probing the female drops slowly into the center of the nest and pushes her extended anal fin between the larger stones at the bottom of the nest.

A nest building female attracts courtship attention from a male. An attending male spends much time hovering just behind or to the side and behind the female, head level with her caudal fir. From the attending position the male may quickly move forward level with the females dorsal fin and quiver. Quiver is a high-frcquency low-amplitude undulation of the body performed close to a holding female or, more often, a probing female.

Spawning usually occurs after a period of frequent and intense probing and quivering: the female drops into the nest, as in probing, accompanied by the male. Both male and female gape, open their mouths wide, vibrate the caudal peduncle and anal fin, and release eggs and a white cloud of milt. The eggs drop into the interstices of the gravel and within $15 \mathrm{sec}$ the female begins covering. Covering digs are relatively gentle digging movements in which the female moves for ward several body lengths displacing small gravel to cover the pocket of eggs. Covering continues for 10 min or more and results in a mound of gravel over the egg pocket and a partially excavated new nest $30-40$ $\mathrm{cm}$ infront of the covered nest. The female may remain quiescent for several hours, holding at the back of the new nest, or she may begin to excavate the new nest and proceed to a second spawning. A female may dig and oviposit into as many as five nests over a period of 3-5 days (Liley et al., in preparation).

(f) Behavioral recording. Fish were established. usually as pairs, in spawning channels set on the stream bed (1982) or in the laboratory (1983). In 1982 channels were checked for $5 \mathrm{~min}$ at hourly intervals between 0800 and $1700 \mathrm{hr}$ and a note made of, (a) any behavioral activity, and (b) presence, position, and size of a nest. In 1983 channels were checked at 2 -hr intervals from 0900 to $1700 \mathrm{hr}$. Even if fish were apparently inactive at the time of the "check" the presence of a nest or a change in the nest was a highly reliable guide to female activity in the preceding hour.

Depending upon their assigned experimental group, fish were removed and blood samples taken before, during, or after spawning: activity. Immediately prior to sampling, a pair was observed for $20 \mathrm{~min}$ and the occurrence of digging. covering, probing, and cquivering acts recorded on a check sheet. Any evidence of spawning, such as a change in the position of the nest or visible eggs, was also noted. If spawning was surspected this could be checked by searching for a "pocket" of eggs in the gravel in the region' of the newly covered nest.

(g) Statistical procedures. Data preserited in the 
figures are the means and standard error. Independent samples were subjected to analysis of variance and Scheffe's test for the comparison of pairs of samples. In cases in which the variances were not homogeneous data were transformed $(\log X+1)$ before statistical testing. A t test was applied in the compar. ison of paired data from serially sampled fish. Unless otherwise indicated the significance level was set at $\alpha$ $=0.05$.

\section{PLASMA HORMONE LEVELS IN FISH SAMPLED IN THE FIELD (1982)}

The following calegories of males were sampled:

(a) Green males. Males were taken from the trap early in the spawning run (June 14) and immediately assessed for reproductive condition by exerting pressure on the abdomen. Males from which only small amounts of milt could be expressed under firm pressure were termed "green," $n=10$, standard length $(\mathrm{SL})=30.5 \mathrm{~cm} \pm$ $0.6 \mathrm{SE}$, weight $=411.7 \mathrm{~g} \pm 20.9 \mathrm{SE}$.

(b) Ripe males. Males with freely running milt, sampled immediately after stripping by hatchery personnel at the trap on June $26, n=10$.

(c) Post-spawning males. Males taken from above the trap on July 1 and 2. These males had evidently completed spawning and were moving downstream to the lake, $n=10, \mathrm{SL}=29.6 \mathrm{~cm} \pm 0.6 \mathrm{SE}$. These fish appeared to be in poor condition: thin, pale-colored, and often with fungal growths over damaged areas of skin. In most cases it was difficult to cxpress any milt and the sex of the fish was determined by dissection.

(d) Courting males. Males actively courting digging and probing females were removed and immediately sampled June $16-31 ; n=4$. Sampling in this group was curtailed by the change in weather conditions, see (e).

(e) Inactive males. Heavy rainfall and snow in early July caused a sudden increase in water level and turbidity, and a lowering of the water temperature from 12 to $6^{\circ}$. Malcs which had previously been ac- tively courting females in the spawning channels became inactive, even though there was no reason to consider them to be in a postspawning condition, July $5 ; n=5$. None of these fish had had the opportunity to spawn and, unlike the postspawning males, were in good condition.

\section{Results}

Gonadotropin levels were similar across the groups of green, ripe, postspawning, and inactive males (Fig. 1). The four actively courting males had levels of gonadotropin higher than all but one of the 35 males in the other four groups. The sample from one individual in the postspawning fish contained $23.76 \mathrm{ng} / \mathrm{ml}$ compared with a maximum of $9.5 \mathrm{ng} / \mathrm{ml}$ in all other groups. If the apparently anomalous individual is omitted from the statistical analysis only the courting males differ significantly from all other groups. There were no significant differences in the levels of 11-ketotestosterone in green, ripe, and courting males (Fig. 1). Mean androgen level had declined in inactive fish and was significantly lower than in the green and courting males. 11Ketotestosterone was not detectable in 8 of 10 postspawning fish.

The progestin, 17,20-P, was detected at similar low levels in green, ripe, postspawning, and inactive males. Courtship activity was associated with a striking and significant increase in this hormone: the lowest level measured in a sexually active fish was $26.61 \mathrm{ng} / \mathrm{ml}$, compared with the highest, $7.43 \mathrm{ng} / \mathrm{ml}$, measured in one of the inactive males.

\section{PLASMA HORMONES IN FISH SPAWNING IN THE LABORATORY (1983)}

The most striking feature of trout sampled in the field was the finding that there were marked increases in GtH and 17,20-P in males allowed to court actively nest building females. This finding suggested that it would be of interest to examine fur- 

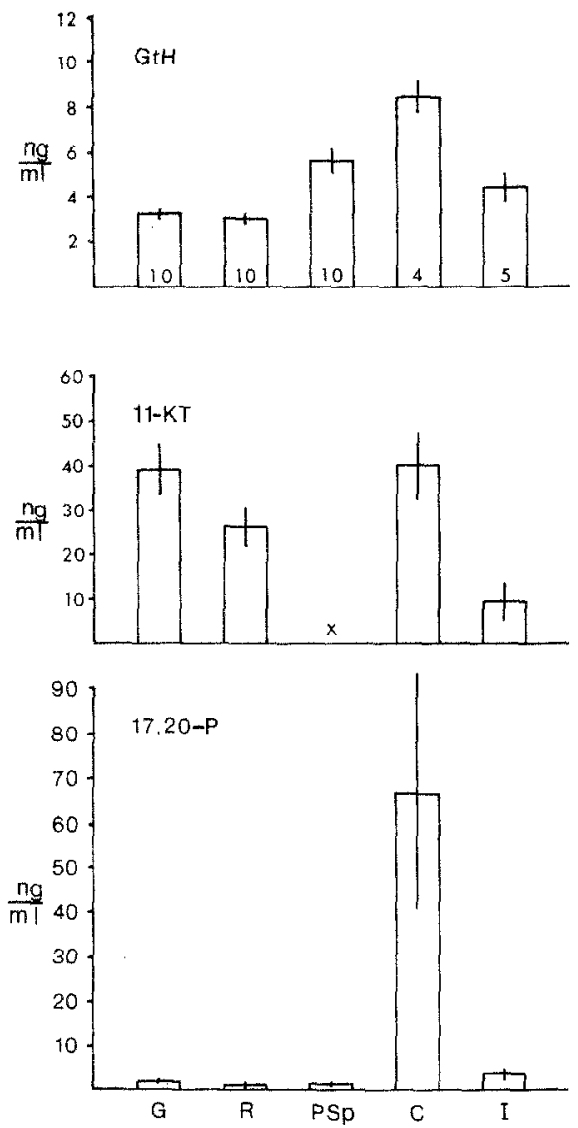

Fig. 1. Plasma levels (mean $\pm \mathrm{SE}$ ) of gonadotropin, (GtH) 11-ketotestosterone (11-KT), and $17 \alpha-$ hydroxy-20ß-dihydroprogesterone $(17,20-\mathrm{P})$ in male rainbow trout sampled at different stages of spawning at a natural spawning area. $G=$ "green" males collected early in spawning season, small amount of milt released under pressure; $\mathrm{R}=$ "ripe" males with freely running milt; $\mathrm{PSp}=$ postspawning; $\mathrm{C}=$ malc collected while actively courting a nest building female; $I=$ males which had not spawned but became sexually inactive because of environmental conditions. Sample size shown at base of each column of upper histogram; $\mathrm{X}=$ undetectable.

ther the short-term changes in hormone levels associated with different stages in the spawning process, and to identify the stimuli responsible for the changes that might occur.

Fish trapped in the inlet to Pennask Lake were transported to Vancouver where they were weighed, measured, tested for reproductive condition, and given a numbered plastic tag. All males proved to be in ripe condition (milt easily expressed) and thus were considered to be in similar condition when they were assigned to one of the following experimental treatments:

(a) Group A. Males were held as a group in a barc holding tank isolated from femalcs $(n=15 ;$ mean SL $=33.13 \mathrm{~cm} \pm 0.68 \mathrm{SE}$; mean weight $328 \mathrm{~g} \pm 22.19 \mathrm{SE}$ ). Blood samples (A1) were taken after 4-6 days, at a time when other males placed with females (Group C) were actively courting.

After the initial blood sample males were either kept in isolation for a further 2-4 days $(\bar{x}=3.1)$ before a second sample was taken (A2, $n=7)$, or were paired with females in a spawning channel and allowed to begin courtship before being resampled (A3, $n=8$ ). In some cases the A3 samples were taken as little as $5 \mathrm{hr}$ after the first (3 fish at $5 \mathrm{hr} ; 1$ fish at $24 \mathrm{hr} ; 1$ at 2 days; 1 fish at 3 days; 2 fish at 4 days). Temperature and flow conditions were similar in the holding tanks and spawning channels.

(b) Group B. Males were paired with green, unovulated females in the spawning channels 1 or 2 days after arrival in the lab $(n=16 ; \mathrm{SL}=32.88 \pm 0.55$; weight 325.63 \pm 15.23). The first blood sample was taken (B1) within the next $48 \mathrm{hr}$, prior to any nestbuilding activity by the females. A second sample (B2) was taken after the female had begun digging and the male commenced active courtship. The interval between the two samples ranged from 24 to $72 \mathrm{hr}$ and was determined by the time at which females commenced reproductive activity.

(c) Group C. Males of the third group ( $n$ $=9 ;$ SL $31.81 \pm 0.58$; weight, $288.13 \pm$ 17.72) were paired with ovulated females within $48 \mathrm{hr}$ of arrival in the lab. In most cases females began nest building within 24 $\mathrm{hr}$ : males were sampled $(\mathrm{C})$ after they had been observed in active courtship.

The procedure outlined above allowed direct comparison of first samples from males isolated from females and substrate 
(A1) with those exposed to green females and substrate (B1) or actively digging females (C). The role of stimuli provided by females and/or substrate in governing plasma hormone levels could be further examined by comparing fish sampled serially within groups $\mathrm{A}$ and $\mathrm{B}$.

\section{Results}

GtH levels remained low and similar in the isolated fish (A1) in both first and second (A2) samples (Fig. 2), but increased significantly in the males paired with females (A3). All females were actively nest digging and probing (only 5 were recorded): males attended the females and quivered frequently (Table 1). The magnitude of the increase in plasma hormone was not obviously related to the length of time between first and second samples (Table 2).

- There was no significant difference between first and second samples from males paired with green females (B1) which became sexually active (B2), (Fig. 2). Males paired with green females (B1) or active females (C) had significantly higher GtH levels than the isolated males (A1); B1 and $\mathrm{C}$ did not differ.

Plasma levels of testosterone increased in the previously isolated males paired with active females (Fig. 2) (A1<A3). There appears to have been a slight decrease in males maintained in isolation (A2) but the difference between $\mathrm{A} 1$ and $\mathrm{A} 2$ is not significant, whereas the difference between A2 and $A 3$ is significant.

There was no difference in plasma $11-\mathrm{KT}$ when isolated males $(\Lambda 1)$, and thosc with green females (B1) or active females $(C)$ are compared (Fig. 2). There appeared to be an increase in 11-KT levels in previously isolated males placed with active females but the difference between $A 3$ and $A 1$ was not significant, although the difference between A2 and-A3 was significant. However, there was a significant decrease in
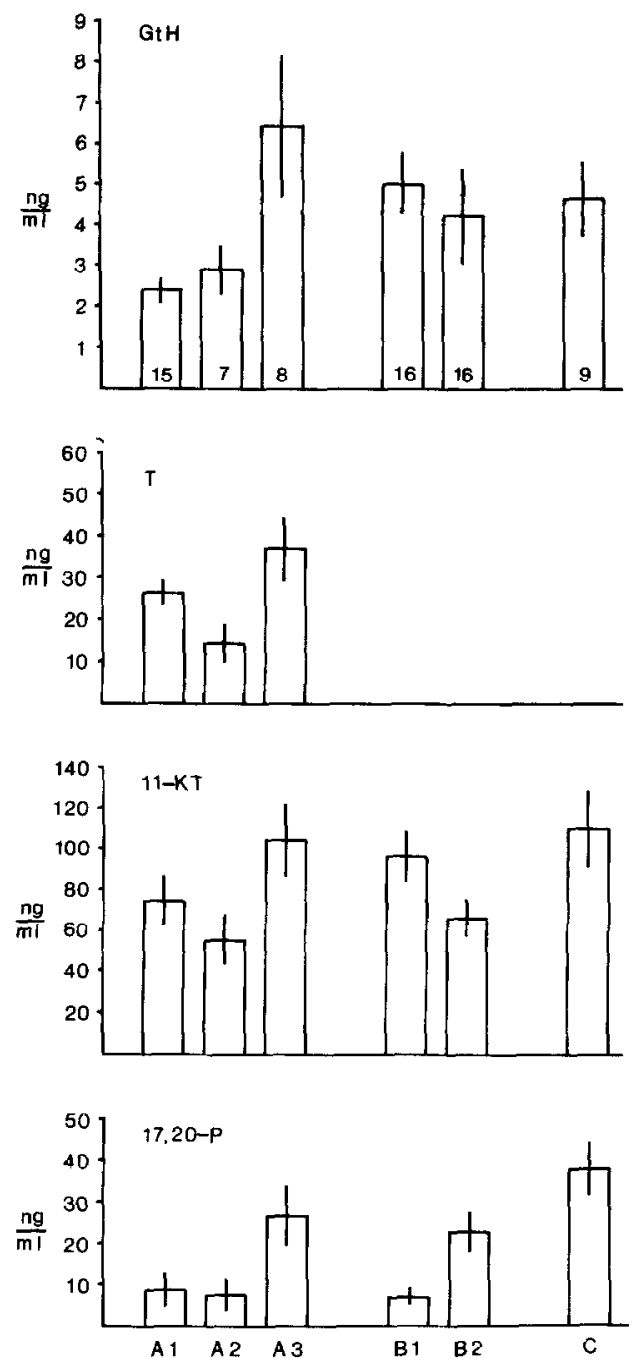

FIG. 2. Plasma levels (mean $\pm \mathrm{SE}$ ) of gonadotropin $(\mathrm{GtH})$, 11-ketotestosterone (11-KT), testosterone (T), and $17 \alpha$-hydroxy-20ß-dihydroprogesterone $(17,20-\mathrm{P})$ in male rainbow trout sampled in laboratory spawning channels. Group A: A1-isolated from females; A2-2nd sample from males maintained in isolation from females; A3-resampled during courtship of nest building female. Group B: B1-males placed with unovulated, sexually inactive females; B2-2nd sample taken after female commenced nest building and male began courtship. Group C: males courting ovulated nest building females. Sample size shown at base of each column of upper histogram.

11-KT in the males paired with green females which later became active (compare B1 with B2). 
TABLE 1

Male and Female Prespawning Behavior in 20 min Observation Priok 1u Taking Bluou Samlee

\begin{tabular}{|c|c|c|c|c|c|}
\hline \multirow[b]{2}{*}{ Male group } & \multirow[b]{2}{*}{$n^{a}$} & \multirow{2}{*}{$\begin{array}{l}\text { Female } \\
\text { condition }\end{array}$} & \multirow{2}{*}{$\begin{array}{l}\text { Bouts of quiver } \\
\text { by male } / 20 \mathrm{~min}\end{array}$} & \multicolumn{2}{|c|}{$\begin{array}{c}\text { Bouts of female activity } \\
\text { per } 20 \mathrm{~min}\end{array}$} \\
\hline & & & & Dig & Probe \\
\hline A3 & 5 & Ovulated & $14.8 \pm 3.8$ & $14.8 \pm 2.9$ & $21.2 \pm 6.5$ \\
\hline $\mathrm{BI}$ & 16 & Unovulated & $2.0 \pm 0.7$ & 0.1 & 0 \\
\hline $\mathrm{B} 2$ & 14 & Ovulated & $15.4 \pm 3.1$ & $9.8 \pm 1.7$ & $29.6=6.4$ \\
\hline $\mathrm{C}$ & 8 & Ovulated & $23.2 \pm 2.7$ & $14.0 \pm 3.2$ & $22.2 \pm 4.0$ \\
\hline
\end{tabular}

"Number of pairs for which 20 -min observations were recorded.

Plasma 17,20-P showed the most striking changes. There was a marked, significant difference between isolated males (A1) and males paired with active femalcs (C). Males paired with green females (B1) did not differ from isolated males (A1). In males of group A, 17,20-P levels increased after exposure to active females (A3) but remained low in males retained in isolation (A2). In group $\mathrm{B}, 17,20-\mathrm{P}$ increased significantly as the females became active (compare B1 and $B 2$ ) to a level not different from other males paired with nest building females (A3 and $\mathrm{C}$ ).

One of the objectives of this study was to determine whether endocrine changes could be correlaled with particular behavioral events such as courtship and

TABLE 2

INTERVAL BETWEEN SUCCESSIVE SAMPLES, AND Plasma GtH AND 17,20-P IN ISOLATED Males (A1) and after Placing WITH Nest BuLlding Females (A3)

\begin{tabular}{|c|c|c|c|c|c|}
\hline \multirow[b]{2}{*}{ Male } & \multirow{2}{*}{$\begin{array}{c}\text { Interval } \\
\text { between } \\
\text { samples (hr) }\end{array}$} & \multicolumn{2}{|c|}{$\begin{array}{l}\text { Gonadotropin } \\
\quad(\mathrm{ng} / \mathrm{ml})\end{array}$} & \multicolumn{2}{|c|}{$\begin{array}{c}17,20-\mathrm{P} \\
(\mathrm{ng} / \mathrm{ml})\end{array}$} \\
\hline & & $\mathrm{A} 1$ & $\mathrm{~A} 3$ & $\mathrm{~A} 1$ & A3 \\
\hline 111 & 5 & 0.84 & 2.70 & 2.25 & 2.64 \\
\hline 113 & 48 & 2.93 & 14.91 & 4.42 & 31.03 \\
\hline 114 & 5 & 1.51 & 4.86 & 2.9 & 25.6 \\
\hline 118 & 5 & 3.33 & 13.34 & 9.18 & 46.24 \\
\hline 140 & 72 & 1.49 & 1.77 & 2.21 & 4.6 \\
\hline 144 & 24 & 2.46 & 6.26 & 59.66 & 55.45 \\
\hline 147 & 96 & 3.52 & 4.28 & 1.61 & 9.81 \\
\hline 148 & 96 & 0.29 & 3.43 & 4.42 & 36.43 \\
\hline
\end{tabular}

spawning. The majority of samples from $\mathrm{A} 3, \mathrm{~B} 2$, and $\mathrm{C}$ were taken from fish which were actively courting nest building females, but had not spawned by the time the blood sample was taken (Table 1). Males in these groups quivered alongside females at mean rates ranging from 14 to $23 / 20 \mathrm{~min}$. Seven of 16 males paired with inactive females (B1) performed small numbers of quivers. The results presented above indicate that active courtship of nest building females is accompanied by an increase in GtH, 17,20-P and, to a lesser extent, $\mathrm{T}$ and 11-KT. In a few cases it was possible to identify males which had spawned less than $2 \mathrm{hr}$ before the blood sample was taken ( $n$ $=7)$ or within the previous $24 \mathrm{hr}(n=5)$. There was no indication that a recent spawning was associated with a change in $\mathrm{GtH}, 17,20-\mathrm{P}$, or androgen over and above those typical of an actively courting male.

\section{DISCUSSION}

Scott et al. (1980), Schulz (1984), and Baynes and Scott (1985) have described the annual cycles of plasma testosterone and 11-ketotestosterone in male rainbow trout. In spite of some interstrain differences the general pattern that emerges is that starting 12 weeks or more before the normal spawning time $\mathrm{T}$ increases gradually to a peak which occurs several weeks before spawning. Changes in $T$ are followed, with 
a delay of 2-4 weeks, by similar changes in $11-\mathrm{KT}$ which reaches a higher concentration than $\mathrm{T}$. The peak in 11-KT occurs shortly before or during spawning. (Note: in none of these and other laboratory studies were males allowed to go through a natural spawning process: spawning period is identified on the basis of the presence of expressible milt.) Plasma $T$ and, to a lesser extent, 11-KT have already begun to decline at the time of spawning, but do not reach their lowest levels for another 12 weeks or more. The same general pattern, an increase in $\mathrm{T}$ followed by $11-\mathrm{KT}$, is found in other salmonids (Salvelinus fontinalis, Sangalang and Freeman, 1974; Salmo salar, Hunt et al., 1982, StuartKregor et al., 1981; Salmo trutta, Kime and Manning, 1982; Oncorhynchus rhodurus, Ueda et al., 1983b; O. keta, Ueda et al., 1984). The occurrence of high plasma levels of $11-\mathrm{KT}$ just prior to, or during, spawning and maximum development of second sexual characteristics has led to suggestions that this is the primary active androgen in male salmonids and perhaps other species.

The progestin, 17,20-P, has been measured in males of several species and appears to be associated particularly with the spawning period (Oncorhynchus nerka, Schmidt and Idler, 1962; Salmo gairdneri, Scott and Baynes, 1982, Baynes and Scott, 1985; O. rhodurus, Ueda et al., 1983a; $O$. keta, Ueda et al., 1984).

Because in this investigation fish were sampled over a short span of time surrounding spawning it is not possible to make a detailed comparison with the seasonally changing hormone profiles recorded elsewhere. Nevertheless, the present findings are consistent with previous reports. Testosterone, $11-\mathrm{KT}$, and 17,20-P were all detected in the plasma of males in spawning condition. Testosterone, measured in one group only, was at a lower concentration than 11-KT, a finding in keeping with reports that maximum $\mathrm{T}$ levels are lower than 11-KT, and that the decline in $\mathrm{T}$ precedes that of 11-KT.

In contrast with several of the reports referred to above, 11-KT became undetectable in most male rainbow trout less than 2 weeks after the peak of the spawning season. This may be a reflection of the fact that, in comparison with hatchery stocks, postspawning Pennask Lake males are in poor condition and most do not survive long after spawning. Unlike males sampled in hatcheries the spawned-out males were presumably exhausted after several days spent competing vigorously with other males for the opportunity to spawn with nest building females.

Plasma GtH levels peak around the time of spawning in rainbow trout (Billard et al., 1978; Sanchez-Rodriguez et al., 1978); Oncorhynchus rhodurus, (Ueda et al., 1983b), and other salmonids (Crim et al., 1975; Stuart Kregor et al., 1981). GtH was present at moderately high levels in all groups examined here. GtH was significantly elevated in males courting nest building females and declined in postspawning fish to levels found in ripe but unpaired males.

A finding of major interest in this study is the demonstration of a social control of hormone levels. There were striking increases in both GtH and 17,20-P in males placed with nest building females. There are parallel but less marked changes in $\mathrm{T}$ and 11-KT in males isolated and then paired with active females (group A). However, in males paired with green females (B1) there was a significant decrease in 11-KT as the females became sexually active (B2).

Which components of the spawning situation provide the effective stimuli is not clear. Green inactive females over a spawning substrate were as effective as nest building ovulated females in causing an elevation of $\mathrm{GtH}$ in males. But, in 
marked contrast, 17,20-P did not increase unless the stimulus female was actively nest building. Males performed very little courtship of green females, but were highly active and persistent in the presence of ovulated nest building females. Thus, contrary to the expectation that an increase in $17,20-\mathrm{P}$ follows and is the result of a rise in $\mathrm{GtH}$, the lack of a positive correlation between the changes in $\mathrm{GtH}$ and 17,20-P suggest that levels of the steroid are not completely dependent upon GtH. The rapid increase in 17,20-P in one group (A3), within $5 \mathrm{hr}$ of exposure to a nest building female, makes it unlikely that the low level of progestogen in males paired with green females is simply a result of a delay in secretion or release of $17,20-\mathrm{P}$, and raises the possibility that steroid secretion might be in part under neural control as has been reported in mammals (Kawakami et al., 1981). Van den Hurk et al. (1982) have reported nerve terminals ending on interstitial cells of the testis of rainbow trout.

There are few other demonstrations of a social control of hormone levels in fish. Kyle et al. $(1982,1985)$ found that GtH measured in male goldfish rose within $2 \mathrm{hr}$ of a male being placed with a spawning pair. Contact with the spawning fish was a necessary component of the stimulus causing the endocrine change. In male Haplochromis burtoni and Xiphophorus heleri social isolation leads to a reduction in blood androgen and conticosteroid (Hannes and Franck, 1983), and it is proposed that social stimuli cause an increase in androgens and that this leads to higher levels of aggression.

Other less direct evidence points to the role of social stimuli in modulating endocrine levels. Stacey et al. (1984) noted that in white suckers Catostomus commersoni the onset of spawning was generally associated with a dramatic increase in GtH. GtH levels were low in groups of males from a site at which no females were present, and in the prolonged spawning season of $1982 \mathrm{GtH}$ levels declined after the first few days of spawning and all males had similar GtH levels regardless of reproductive state. Stacey et al. suggest that this low GtH may have resulted from the small number of ovulated females present at the time.

The functional roles of testosterone and $11-\mathrm{KT}$ in male fish have been reviewed by Fostier et al. (1983). Androgens have been implicated in sexual differentiation, sper. matogenesis, and spermiation, and the development of secondary sexual characteristics. Of particular interest here is the possible role of androgens in spermiation and the production of mill-processes characteristic of the spawning male.

Baynes and Scott (1985) have emphasized the distinction between spermiation (the escape of spermatozoa from cysts formed by Sertoli cells into the testicular tubules) and milt production. The latter depends upon the migration of spermatozoa into the vas deferens where seminat fluid is formed. Baynes and Scott (1985) suggest that spermiation is already complete shortly after the start of milt production.

The onset of milt production in rainbow trout appears to be associated with high androgen levels (Fostier et al., 1982; Sanchez-Rodriguez et al., 1978; Scott et al., 1980; Baynes and Scott, 1985). Fostier et al. (1984) report that the volume of strippable mill decreased in parallel with a decrease in $11-\mathrm{KT}$. Other reports indicate that although the onset of milt formation occurs when androgen levels are high, milt production is maintained or even increased as androgen levels decline (Baynes and Scott, 1985). Ueda et al. (1983b) and Uedaet al. (1984) found a marked drop in total androgens in two species of Pacific salmon from the prespawning to spawning period. These observations suggest that, even though androgens play a key role in the final stages of spermatogenesis and sper- 
miation, it is unlikely that high levels of androgen are essential to the maintenance of milt production.

In contrast to the declining androgen levels in spawning fish, 17,20-P increases dramatically at the time of spawning in trout (Baynes and Scott, 1985) and Pacific salmon (Ueda et al., 1983a; Ueda et al., 1984). Baynes and Scott (1985) noted a close correspondence between the mean number of spermatozoa that could be stripped and the plasma levels of 17,20-P.

The role of $17,20-\mathrm{P}$ in male fish remains poorly understood (Fostier et al., 1983). Scott and Baynes (1982) found that injections of $17,20-\mathrm{P}$ had no effect on milt volume or number of spermatozoa, but did cause an increase in the ratio, $\mathrm{K}^{+}: \mathrm{Na}^{+}$. In two of three stocks examined, Baynes and Scott (1985) found a close association between 17,20-P levels and the $\mathrm{K}^{+}$concentration of seminal fluid. Baynes et al. (1981) had earlier suggested that a major effect of a high $\mathrm{K}+$ is to inhibit activation of spermatozoa prior to release. Baynes and Scott (1985) propose that a major function of $17,20-\mathrm{P}$ in the male is the control of sperm motility mediated by changes in $\mathrm{K}^{+}$ composition of the seminal fluids.

There is some evidence that milt volume and characteristics may be affected by social stimuli. Kyle et al. (1982) measured an increase in expressible milt volumes in male goldfish exposed to spawning pairs. Working with rainbow trout, Büyükhatipoglu and Holtz (1984) examined the effect of the presence of mature females upon milt production. In one season males placed with females showed a significant increase in milt volume (23\%) and sperm number (18\%). No significant effect was observed in the second season. Sperm density and motility were not affected in any group. In spite of their results and earlier reports referred to in their paper, Büyükhatipoglu and Holtz (1984) conclude that the effect of the females on the reproductive function of the males "was not very evident." It should be noted that in their ex- periments the sexes were prevented from coming into physical contact by a screen partition, thereby reducing the level of stimulation of the male. Any effect of the female on the male must have been mediated by chemical or limited visual cues.

Milt volumes and characteristics were not measured in this study. However, it was clear that the so-called green males released only small volumes of milt under firm pressure, whereas a few days later the same individuals, actively courting females, would release larger volumes of freely running milt. Our own observations and those of Büyükhatipoglu and Holtz (1984) strongly suggest that at least one of the effects of the endocrine response to a nest building female is an increase in the volume of milt. This results in a synchronization of maximum male fertility with oviposition readiness in the female.

This change in milt production may be a direct effect of the increase in $\mathrm{GtH}$, or it may reflect the increase in $17,20-P$. The elevation in $\mathrm{GtH}$ may also be responsible for the slight but significant increase in $\mathrm{T}$ and 11-KT recorded in previously isolated fish.

At the present time there is no evidence to implicate the hormones measured in this study in the control of spawning behavior. Although androgens have been shown to regulatc reproductive bchavior in a wide variety of species of teleost (Liley and Stacey, 1983) virtually nothing is known of their role in the causation of spawning behavior in salmonids. The preponderance of 11-KT late in the cycle and close to the time of spawning suggests that $11-\mathrm{KT}$ rather than testosterone (which is also present in large quantities in the female) may be more directly involved in the maintenance of sexual behavior. However, the decline in 11-KT which may precede or coincide with the spawning period in some populations examined implies that high 11-KT levels are not necessary for the maintenance of sexual responsiveness.

There is no evidence that $17,20-\mathrm{P}$ plays a 
causal role in the onset and maintenance of spawning activity. The clear association between high 17,20-P levels and the spawning period suggest that this possibility should be examined further.

\section{ACKNOWLEDGMENTS}

We thank Mr. H. Sparrow, Dr. A. Tautz, Mr. L. Lemke, and Mr. G. Tyler of the Fisheries Branch of the B.C. Ministry of Environment for their assistance in making this study possible. Mr. J. Cardwell and $J$. McKinnon gave valuable help in collecting samples and making observations, and Mrs. M. O. Marcuzzi and E. Sambroni provided skillful assistance with the RIA. Dr. J. Sumpter and Dr. N. E. Stacey kindly read the manuscript and offered many suggestions. This research was supported by a NSERC Grant to N.R.L. Dr. E. S. P. Tan visited Canada while in receipt of a NSERC/CIDA Research Associateship.

\section{REFERENCES}

Baynes, S. M., Scott, A. P., and Dawson, A. P. (1981). Rainbow trout, Salmo gairdneri, Richardson, spermatozoa: Effects of cations and $\mathrm{pH}$ on motility. J. Fish Biol. 19, 259-267.

Baynes, S. M., and Scott, A. P. (1985). Seasonal variations in parameters of milt production and in plasma concentration of sex steroids of male rainbow trout (Salmo gairdneri). Gen. Comp. Endocrinol. 57, 150-160.

Büyükhatipoglu, S., and Holtz, W. (1984). Sperm output in rainbow trout (Salmo gairdneri): Effect of age, timing and frequency of stripping and presence of females, Aquaculture 37, 63-72.

Billard, R., Breton, B., Fostier, A., Jalabert, B., and Weil, C. (1978). Endocrine control of the teleost reproductive cycle and its relation to external factors: salmonid and cyprinid models. In "Comparative Endocrinology" (P. J. Gaillard and H. H. Boer, eds.), pp. 37-48. Elsevier-North Holland Biomedical Press.

Breton, B., Prunet, P., and Reinaud, P. (1978). Sexual differences in salmon gonadotropin. Ann. Biol. Anim. Biochem. Biophys. 18, 759-765.

Crim, L. W., Watts, E. G., and Evans, D. M. (1975). The plasma gonadotropin profile during sexual maturation in a variety of salmonid fishes. Gen. Comp. Endocrinol. 27, 62-70.

Fostier, A., Jalabert, B., Campbell, C., Terqui, M., and Breton, B. (1981). Cinétique de libération in vitro de $17 \alpha$ hydroxy-20ßdihydroprogestérone par des follicules de Truite arc-en-ciel, Salmo gairdneri. C.R. Acad. Sci. Paris, 292, 777-780.

Fostier, A., Billard, R., Breton, B., Legendre, M., and Marlot, S. (1982). Plasma 11 oxo-testosterone and gonadotrophin during the beginning of spermiation in rainbow trout (Salmo gairdneri R.). Gen. Comp. Endocrinol 46, 428-438.

Fostier, A., Jalabert, B., Billard, R., Breton, B., and Zohar, Y. (1983). The Gonadal Steroids. In "Fish Physiology" (W. S. Hoar, D. 'J. Randall; and E. M. Donaldson, eds.), Vol. IXA, pp. 277-372. Academic Press, New York.

Fostier, A., Billard, R., and Breton, B. (1984). Plasma 11-oxotestosterone and gonadotropin in relation to the arrest of spermiation in rainbow trout (Salmo gairdneri). Gen. Comp. Endocrinol. 54, 378-381.

Hannes, R.-P., and Franck, D. (1983). The effect of social isolation on androgen and corticosteroidlevels in a cichlid fish (Haplochromis burtoni) and in swordtails (Xiphophorus helleri), Horm. Behav. 17, 292-301.

Harding, C. F. (1981). Social modulation of circulating hormone levels in the male. Amer. Zool. 21, 223-231.

Hunt, S. M. V., Simpson, T. H., and Wright, R. S: (1982). Seasonal changes in the levels of 11-oxotestosterone and testosterone in the serum of male salmon. Salmo salar L., and their relationship to growth and maturation cycle. J. Fish Biot. 20, 105-119.

Hurk, R., van den, Lambert, J. G. D., and Peute, J. (1982). Steroidogenesis in the gonads of rainbow trout fry (Salno gairdneri) before and after the onset of gonadal sex differentiation. Reprod. Nutr. Dev. 22, 413-425.

Kawakami, M., Kubo, K.. Uemura, T. Nagase, M., and Hayashi, R. (1981). Involvement of ovarian innervation in steroid secretion. Endocrinology $109,136-145$.

Kyle, A. L., Stacey, N. E., and Peter, R. E. (1982); Sexual stimuli associated with increased gonadom tropin and milt levels in goldfish. In "Proceedings of the International Symposium on Reproductive Physiology of Fish" (C. J. J. Richter and H. I. Th. Goos, eds.), p. 240. Purloc Wageningen, Netherlands.

Kyle, A. L., Stacey, N. E., Peter, R, E., and Billard. R. (1985). Flevations in gonadotrophin concentrations and milt volumes as a result of spawning behavior in the goldfish. Gen. Comp. Endocrinol. $57,10-22$.

Kime, D. E., and Manning, N. J. (1982). Seasonal patterns of free and conjugated androgens in the brown trout, Salmo tritta. Gen. Comp. Endocrinol. 48, 222-231.

Lam, T. J. (1983). Environmental influences on gonadal activity in fish. In "Fish Physiology" (W. S. Hoar, D. J. Randall, and E. M. Donaldson, eds.), Vol. IXB, pp. 65-116. Acadentic Press, New York.

Licht, P., McCreery, B. R., Barnes, R., and Pang. R. 
(1983). Seasonal and stress related changes in plasma gonadotropins, sex steroids, and corticosterone in the bullfrog, Rana catesbeiana. Gen. Comp. Endocrinol: 50, 124-145.

Liley, N. R. (1980). Patterns of hormonal control in the reproductive behavior of fish, and their relevance to fish management and culture programs. In "Fish Rehavior and Its Use in the Capture and Culture of Fishes" (J. E. Bardach, J. J. Magnuson, R. C. May, and J. M. Reinhart, eds.), ICLARM Conference proceedings 5, 210-246. International Center for Living Aquatic Resources Management, Manila, Philippines.

Liley, N. R., and Stacey, N. E. (1983). Hormones, pheromones and reproductive behavior in fish. In "Fish Physiology" (W. S. Hoar, D. J. Randall, and E. M. Donaldson, eds.), Vol. IXB, pp. 1-63. Academic Press, New York.

Peter, R. E. (1983). The brain and neurohormones in teleost reproduction. In "Fish Physiology" (W. S. Hoar, D. J. Randall, and E. M. Donaldson, eds.), Vol. IXA, pp. 97-136. Academic Press, New York.

Sanchez-Rodriguez, M., Escaffre, A. M., Marlot, S., and Reinaud, P. (1978). The spermiation period in the rainbow trout (Salmon gairdneri). Plasma gonadotrophin and androgen levels, sperm production and biochemical changes in the seminal fluid. Ann. Biol. Anim. Biochim. Biophys. 18, 943-948.

Sangalang, G. B., and Freeman, H. C. (1974). Effects of sublethal cadmium on maturation and testosterone and 11-ketotestosterone production in vivo in brook trout. Biol. Reprod. 11, 429-435.

Schmidt, P. J., and Idler, D. R. (1962). Steroid hormones in the plasma of salmon at various states of maturation. Gen. Comp. Endocrinol. 2, 204-214.

Schultz, R. (1984). Serum levels of 11-oxotestosterone in male and $17 \beta$-Estradiol in female rainbow trout (Salmo gairdneri) during the first reproductive cycle. Gen. Comp. Endocrinol. 56, 111-120.

Scott, A. P., and Baynes, S. M. (1982). Plasma levels of sex steroids in relation to ovulation and spermiation in rainbow trout (Salmo gairdneri). In "Proceedings of the International Symposium on Reproductive Physiology of Fish" (C. J. J. Richter and H. J. Th. Goos, eds.), pp. 103-106. Pudoc, Wageningen, Netherlands.
Scott, A. P., Bye, V. J., Baynes, S. M., and Springate, J. R. C. (1980). Seasonal variations in plasma concentrations of 11-ketotestosterone and testosterone in male rainbow trout, Salmo gairdneri Richardson. J. Fish. Biol. 17, 495-505.

Scott, A. P., MacKenzie, D. S., and Stacey, N. E. (1984). Endocrine changes during natural spawning in the white sucker, Catostomus commersoni. II. Steroid hormones. Gen. Comp. Endocrinol. 56, 349-359.

Silver, R., and Cooper, M. (1983). Avian behavioral endocrinology. Bioscience 33, 567-572.

Stacey, N. E., MacKenzie, D. S., Marchant, T. A., Kyle, A. L., and Peter, R. E. (1984). Endocrine changes during natural spawning in the white sucker, Catostomus commersoni. I. Gonadotropin, growth hormone, and thyroid hormones. Gen. Comp. Endocrinol. 56, 333-348.

Stuart-Kregor, P. A. C., Sumpter, J. P., and Dodd, J. M. (1981). The involvement of gonadotrophin and sex steroids in the control of reproduction in the parr and adults of Atlantic salmon, Salmo salar L. J. Fish. Biol. 18, 59-72.

Tautz, A. F., and Grool, C. (1975). Spawning behavior of chum salmon (Oncorhynchus keta) and rainbow trout (Salmo gairdneri). J. Fish. Res. Board Canad. 32, 633-642.

Ueda, H., Young, G., Crim, L. W., Kambegawa, A., and Nagahama, Y. (1983a). 17 $\alpha, 20 \beta$ dihydroxy-4pregnen-3-one: Plasma levels during sexual maturation and in vitro production by the testes of amago salmon (Oncorhynchus rhodurus) and rainbow trout (Salmo gairdneri). Gen. Comp. Endocrinol. 51, 106-112.

Ueda, H., Nagahama, Y., Tashiro, F., and Crim, L. W. (1983b). Some endocrine aspects of precocious sexual maturation in amago salmon Oncorhynchus rhodurus. Bull. Jap. Soc. Scient. Fish. 49, 587-596.

Ueda, H., Hiroi, O., Hara, A., Yamauchi, K., and Nagahama, Y. (1984). Changes in serum concentration of steroid hormones, thyroxine, and vitellogenin during spawning migration of chum salmon, Oncorhynchus keta. Gen. Comp. Endocrinol. 53, 203-211.

Zohar, Y., and Billard, R. (1984). Annual and daily changes in plasma gonadotropin and sex steroids in relation to teleost gonad cycles. Trans. Amer. Fish. Soc. 113, 444-451. 